\title{
Dopamine transporter phosphorylation site threonine 53 regulates substrate reuptake and amphetamine-stimulated efflux
}

\author{
Jae-Won Yang ${ }^{1}$, James D Foster ${ }^{2}$, Amy E Moritz², Sathyavathi ChallaSivaKanaka², Margaret A Smith², Marion Holy, \\ Kyle Wilebski ${ }^{2}$, Roxanne A Vaughan², Harald H Sitte ${ }^{1^{*}}$
}

From 18th Scientific Symposium of the Austrian Pharmacological Society (APHAR). Joint meeting with the Croatian, Serbian and Slovenian Pharmacological Societies.

Graz, Austria. 20-21 September 2012

\section{Background}

In the central nervous system, levels of extraneuronal dopamine are controlled primarily by the action of the dopamine transporter (DAT). Multiple signaling pathways regulate transport activity, substrate efflux, and other DAT functions through currently unknown mechanisms but presumably by oligomerization, protein-protein interactions and post-translational modification, such as phosphorylation. DAT is phosphorylated by protein kinase $\mathrm{C}$ within a serine cluster at the distal end of the cytoplasmic $\mathrm{N}$-terminus, while recent work in model cells revealed proline-directed phosphorylation of rat DAT at membrane proximal residue Thr53. However, specific phosphorylation sites in native DAT under basal condition with associated functional properties have not been ascertained so far.

\section{Methods}

We (i) applied mass spectrometry in rodent striatal tissue and heterologous cell systems to identify in vivo phosphorylation sites (ii) generated a phospho-specific antibody (pT53Ab) for the confirmation of the identified phosphorylation site and for the determination of a stoichiometry of phosphorylation, involvement of PKC and phosphatase. Functional implications of this identified phosphorylation site have been tested by dopamine uptake and amphetamine-stimulated substrate efflux.

\section{Results}

Phosphorylation of Thr53 (pThr53), occurred with a stoichiometry of $\sim 50 \%$ under basal condition in rat striatal tissue, was unambiguously identified by mass spectrometry and immunoassay with phospho-specific antibody. pThr53 was strongly increased by phorbol esters and protein phosphatase inhibitors. Mutations of Thr53 to alanine to mimic dephosphorylation reduced dopamine transport $\mathrm{V}_{\max }$ and ablated amphetamineinduced substrate efflux.

\section{Conclusions}

DAT is constitutively phosphorylated at Thr53 and its phosphorylation/dephosphorylation status plays a role in the transport mechanism, particularly in dopamine uptake and amphetamine-stimulated substrate efflux.

\footnotetext{
Acknowledgements

This work was supported by grants R01 DA13147 from the National Institute on Drug Abuse (R.A.V.), ND EPSCoR IIG (R.A.V. and J.D.F.), P20 RR017699 to the University of North Dakota from the COBRE program of the National Center for Research Resources, P20 RR016741 to the University of North Dakota from the INBRE program of the National Center for Research Resources, and the Austrian Research Funds/FWF: grants F3506 and P22893-B1 (H.H.S.) and P23670-B09 (J.W.Y.).

Author details

${ }^{1}$ Institute of Pharmacology, Center for Physiology and Pharmacology, Medical University of Vienna, 1090 Vienna, Austria. ${ }^{2}$ Department of Biochemistry and Molecular Biology, University of North Dakota, School of Medicine and Health Sciences, Grand Forks, ND 58202, USA.

Published: 17 September 2012
}

\footnotetext{
* Correspondence: harald.sitte@meduniwien.ac.at

${ }^{1}$ Institute of Pharmacology, Center for Physiology and Pharmacology,

Medical University of Vienna, 1090 Vienna, Austria

Full list of author information is available at the end of the article
}

(c) 2012 Yang et al; licensee BioMed Central Ltd. This is an Open Access article distributed under the terms of the Creative Commons Attribution License (http://creativecommons.org/licenses/by/2.0), which permits unrestricted use, distribution, and reproduction in any medium, provided the original work is properly cited. 
doi:10.1186/2050-6511-13-S1-A45

Cite this article as: Yang et al:: Dopamine transporter phosphorylation

site threonine 53 regulates substrate reuptake and amphetamine-

stimulated efflux. BMC Pharmacology and Toxicology 2012 13(Suppl 1):A45.

Submit your next manuscript to BioMed Central and take full advantage of:

- Convenient online submission

- Thorough peer review

- No space constraints or color figure charges

- Immediate publication on acceptance

- Inclusion in PubMed, CAS, Scopus and Google Scholar

- Research which is freely available for redistribution

Submit your manuscript at 